\title{
Maja Kleczewska's 2019 Hamlet/Гамлет: \\ A Case of Trans- / Inter-cultural Shakespeare Production in Poland Thirty Years after the Transition
}

\author{
Jacek Fabiszak
}

\begin{abstract}
The article considers a production of Hamlet by Maja Kleczewska at Teatr Polski in Poznań in the context of formal experimentation as well as its political and social ramifications, which are inextricably intertwined. Both the reasons for and consequences of choosing the sitespecific location of the Old Abattoir in Poznan as well as the lack of the division of the production space into stage and auditorium are analysed, with reference to reception processes, the ontological status of spectators and characters as well as the comments, which the production makes on the political and social situation of Poland and Central Europe in 2019 and 2020, especially immigration and marginalised groups within Central European societies.
\end{abstract}

\section{Key words}

site-specific production, experimental, spectating, refugees, marginalised groups 
As the Latin and Glagolithic title suggests, Maja Kleczewska's Hamlet/Гамлет (premier 7 June 2019) is a transcultural production which experiments with the presentation of the story of Hamlet. It challenges audience expectations and harnesses modern technology to explore novel ways of spectating. ${ }^{1}$ It is a site-specific production, originally staged in the area of an old abattoir no longer used for slaughtering animals and turned into a setting for artistic events. The space is not divided into a stage and auditorium, as the audience is invited to share and occupy it with the actors. The action simultaneously develops in different localities (as many as three at a time), with spectators choosing which scene they want to watch. They are equipped with headphones and can switch to one of the three channels transmitting dialogues and soliloquies uttered by characters in different locations. The actors represent different nationalities (Polish, Ukrainian, Russian, Senegalese, etc.) and ethnic groups, and perform in different languages, although Polish dominates. In this way, the production comments on the refugee crisis and Poland's refusal to accept refugees as an EU member as well as on the marginalised groups in a society which is officially homogenous ethnically, but which also frowns upon women and the disabled. Poland, like many Western countries, can be seen as modern in its cult and pursuit of youth and beauty, exemplified by home grown and foreign celebrities, as well as through its putative view of the social and political role of theatre to diagnose and address contemporaneous ills in a form that challenges the traditional theatre-goer spectating comfortably in red plush chairs. ${ }^{2}$

\section{The space: Stara Rzeźnia}

The yellow-brick building constructed in 1900 is a fine example of industrial architecture of the turn of the $19^{\text {th }}$ century. Sadly, the structure was partially pulled down in 2020. It is worth noting that during the $23^{\text {rd }}$ Gdansk Shakespeare Festival in 2019 the production was presented at St. John's church, a cultural and theatrical centre in Gdańsk, and also a non-theatrical location.

Critics (e.g., Bochniarz, Domagała, Dobrowolski, etc.) frequently highlight the location, its appeal and influence on the relationship between the actors and spectators. Maja Kleczewska is known for choosing such non-theatrical venues for her productions; for example, her 2017 Golem was presented at the ATM Studio in Warsaw (produced by Teatr Żydowski [Jewish Theatre]). Kleczewska's Hamlet, produced by Teatr Polski [Polish Theatre] in Poznań, was set in a place deployed for theatrical projects that are usually experimental or fringe in nature (e.g., Pawel Szkotak's Who is This Bloodied Man? by Teatr Biuro Podróży in Poznań, a version of Macbeth). Yet, many Poznań-based spectators do recall that the abattoir was still in use in the early 1990s; as a result, as Anna Wołosz-Sosnowska notes, the space continues to be haunted by a butchery which

1 As Anna Kowalcze-Pawlik notes, the transliteration of the title is often omitted in the reviews (KOWALCZE-PAWLIK 2020). In the article I will use the title in Latin script for the sake of brevity.

2 It is necessary to highlight the fact that the venue of Teatr Polski is a $19^{\text {th }}$-century purpose-built theatre with a proscenium stage and auditorium featuring fairly comfortable though tightly packed seating. 
should not exist in a 'civilised' society and may thus symbolise its downfall, or the ruins of Europe, a topos put forth by Heiner Müller in his Hamletmachine, one of the two texts upon which the script by Maja Kleczewska and dramaturg Łukasz Chotkowski is based (WOŁOSZ-SOSNOWSKA 2020: 2-3). Aneta Kyzioł notes that '[stage designer] Zbigniew Libera covered the devastated floor and walls [of Stara Rzeźnia] with colourful rugs and carpets; in one corner he placed a table, in another a bed and a wardrobe, in another a dais for the actors' (KYZIOŁ 2019). ${ }^{3}$ Of these, the most visible is the red carpet which dominates the perception of the colour palette by the spectators and which Wołosz-Sosnowska associates with the blood of butchered animals (WOŁOSZSOSNOWSKA 2020: 3). Interestingly enough, marginalised and denied from the collective consciousness as this place seems to be, according to Natália Pikli the space has undergone a change and has been re-localised as a culturally central space (PIKLI 2020).

\section{Spectating}

The use of an open space without traditional architectural divisions 'redefines the dynamics of reception' (WOLOSZ-SOSNOWSKA 2020: 3). This strategy can clearly be linked with Kleczewska and Chotkowski's claim that their 'Hamlet is not a spectacle. Hamlet is action', thus emphasising the participatory role of the audience. Spectators are made not to be passive; they are required to make an effort to take in the production, not only following actors but also often literally 'elbowing' their way through a crowd surrounding a scene. As a result, spectators interact not only with the actors but also with each other. Tomasz Domagała accurately captured the rhythm of the crowd as 'like a "shoal of fish", whenever something important was occurring and a scene was evolving, spectators came to "cluster around" the area, naturally shaping the space for performance and spectating, only to after a while "flow away" towards something more interesting' (DOMAGAŁA 2019). In doing so, audience members need to decide whether to follow the crowd or charter their own individual maps of the space.

The audience's circulating among characters makes the spectators an integral part of the performance. Agata Wittchen-Barełkowska (2019) observes that watching the other spectators was as fascinating as watching the actors. Marek S. Bochniarz (2019), too, finds the spectators interesting to observe and even goes so far as to classify and rate the audience's behaviour. The freedom of the spectator consists not only in the ability to roam around the rooms, leaving them and returning to the spaces at will, but primarily in designing their own story of Hamlet, or what Domagała has referred to as the 'three narratives in the [spectators'] headphones' (DOMAGAŁA 2019). Kleczewska explains it in the following way: 
Our [her and Chotkowski's] idea was that everybody could become a director of the production [...]. What is interesting is to participate in the narrative, a subjective, personal perspective. I think it is time the concept of the spectator is defined - does $\mathrm{s} / \mathrm{he}$, immersed in the darkness, merely witness the events on stage, or, perhaps, does $\mathrm{s} / \mathrm{he}$ become a co-author, design the drama themselves, frame the images, edit and choose the soundtrack, and occupy the very centre of action close to the characters? (KLECZEWSKA and CHOTKOWSKI 2019)

Dobrowolski compares this process to surfing the Internet: 'Spectators navigate the web, by which they try to get hold of and make sense of events and individually construed meanings, which they find interesting, and which they can then follow, making their own individual choices' (DOBROWOLSKI 2019). This is a very demanding task, as the simultaneity of acting planes and apparent non-linearity of the action create a sense of chaos which the spectator is expected to bring under control: 'The production is dedicated to a spectator living in the world of multi-tasking and multichannelling' (Kleczewska quoted in KLECZEWSKA and CHOTKOWSKI 2019). Mike Urbaniak considers the organisation of the space and how it can be comprehended in terms of a game: 'spectators can freely move around the whole board of the game' (URBANIAK 2019). ${ }^{4}$

The audience's participation in the production and meaning creation is, however, constrained. The spectators are not expected to fully immerse themselves in the performance. Kleczewska herself openly admits that 'the fourth wall [is] preserved' (Kleczewska quoted in KLECZEWSKA and CHOTKOWSKI 2019), while Chotkowski observes that 'it is only Ophelia who breaks the fourth wall for a moment when she asks the spectators to be witnesses of her madness' (KLECZEWSKA and CHOTKOWSKI 2019).

Anna Kowalcze-Pawlik also does not consider the production to be immersive:

Kleczewska's production [...] differs from [...] truly immersive theatre [...] in that it creates the atmosphere of not just listening, but intimate eavesdropping and plunging into a world in which everybody knows everything about everybody else and nothing can be kept secret. It is an acoustic panopticon which the audience is not meant to be comfortable with, as it evokes questions about the spectator's role as an auditor who collects sounds for their own pleasure as well as for the sake of remembering in order to act on the basis of memories. (KOWALCZE-PAWLIK 2019: 17)

Kowalcze-Pawlik rightly stresses here the experimental manner of spectating which, in her opinion, merges with listening, creating an atmosphere which, to a large degree, comes to emerge as a soundscape that determines the perception of the production: 'sound [...] becomes an element which has a fundamental meaning not only in constructing stage signs and off-stage references; sound becomes the primordial

4 The various acting planes are reminiscent of Medieval pageants created through a series of spaces from which the contemporaneous audience could also freely select for spectating (PIKLI 2020). 
experience of theatre, of opening up to the Other, ${ }^{5}$ which ultimately shapes our relations with the environment' (KOWALCZE-PAWLIK 2019: 14).

Similarly, Dariusz Kosiński comments on the function of sound in the production:

It is in this audio composition that the internal dramaturgy of the production is at its most intense and captivating, designed to a degree by the spectators who, by means of the so-familiar act of switching between various channels, create a kind of patchwork out of the fragments of a well-known text (Shakespeare) and a less-known one [Heiner Mueller]. (KOSIŃSKI 2019)

With the access to the visual representations of scenes often limited (as the crowd blocks the view, or because one chooses not to follow certain characters and can thus only watch a scene screened off in a different place in the acting area), it is the audio-sphere that becomes the most reliable tool in the creation of meaning in the production. Interestingly enough, such a reliance on the aural sphere may perhaps suggest the Elizabethan, 'let's-hear-a-play' conditions of experiencing a performance, since the early modern audience, so much better trained in listening comprehension than the image-centred spectators of today, were able to furnish the empty stage with their own word-triggered pictures of the mind. Furthermore, as Kleczewska's headphoned spectators focus on following the plot and action, observing the space with their eyes also means watching their fellow spectators. As noted on the Teatr Polski website, Kleczewska and Chotkowski seek to lure in the potential spectator with a troubling question: 'Who is watching and who is being watched?', possibly referring to the audience's watching themselves and the characters as well as to the characters observing the audience, which is a logical corollary of creating a liminal space for reality and fiction.

5 The notion of the $\mathrm{O} / \mathrm{o}$-ther has been one of more salient and productive concepts in post-modern theorisation, especially in psychoanalytical and post-colonial studies (see ASHCROFT, GRIFFITHS and TIFFIN 2007: 154-158). My use of this term is, on the one hand, in its most fundamental sense, viz. as 'anyone who is separate from one's self. The existence of others is crucial in defining what is "normal" and in locating one's own place in the world' (ASHCROFT, GRIFFITHS and TIFFIN 2007: 154). This understanding is crucial in the positioning of such a figure in Kleczewska's production in the context of non-Poles and/or non-white inhabitants of Poland, an issue the production addresses. On the other hand, I find the post-colonial sense of the 'other' also applicable to the linguistically and ethnically marked characters. Frantz Fanon in his classic study was perhaps the first to outline the process of othering: 'The governing race is first and foremost those who come from elsewhere, those who are unlike the original inhabitants, "the others"' (FANON 1963: 40). Similarly, Gayatri Spivak speaks of practices and discourses which aim at 'establishing the "native" as self-consolidating other' (SPIVAK 1985: 250). In the light of the uneasy Polish-Ukrainian relations and turbulent history, Poland is perceived in Ukraine as 'Empire' which has consistently produced discourses of othering, despite the fact that Western Ukraine has long ceased to lie within the borders of Poland, while Ukraine is often presented, especially in the right-wing political discourse, as responsible for the ethnic cleansing in Volhynia during WWII, which also seems to belong to the othering idiom.

6 See http://teatr-polski.pl/spektakle/hamlet-\%D0\%B3\%D0\%B0\%D0\%BC\%D0\%BB\%D0\%B5\%D1\%82/. 


\section{The voices and faces of the Other}

Kowalcze-Pawlik notes also the significance of sound in the context of a multi-ethnic, multi-national, multi-cultural, multi-linguistic production (KOWALCZE-PAWLIK 2019: 14). As Obarska observes, the homogeneous world is falling apart making room for variety and difference, which explains why actors of different national and ethnic backgrounds have been cast, including performers from Poland (Teresa Kwiatkowska as Ophelia, Michał Sikorski as Horatio, Michał Kaleta as Claudius), Ukraine (Roman Lutskiy as Hamlet), Russia (Alona Szostak as Gertrude), India, Senegal, South Africa (respectively, Mandara Purandare, Gamou Fall and Flaunette Mafa, all of them as a collective Fortinbras) (OBARSKA 2019). They speak or use different languages - Polish, Ukrainian, Sanskrit, etc. Perhaps it is not yet a Babel tower with projections of creative chaos and power, but such associations might cross the spectator's mind. Obviously, besides the formal experimentation, Kleczewska and Chotkowski have most often been asked by critics about the multinational cast and the variety of languages (as featured in material on the Internet site of Teatr Polski in Poznan ${ }^{7}$ and in the very title of the production itself).

The starting point of the director and dramaturg was the premise that 'Hamlet holds here and now a dialogue between generations and cultures' ${ }^{8}$ Interestingly, the comments refer to Lutskiy's impersonation of the character, not the play Hamlet. Thus, the artists stress the significance of the protagonist and define his role in the production: neither Hamlet the avenger nor Hamlet the thinker, etc., but Hamlet the inquirer and moderator. Furthermore, in an aspect often absent in the reviews of the play, the production is not only about diversity of nation, ethnicity, or gender; nor difference in terms of physical and mental acuity, but also age diversity. Łukasz Chotkowski sums up this desire to emphasise multiplicity: 'In the space of Stara Rzeźnia everybody is equal' (KLECZEWSKA and CHOTKOWSKI 2019), with equality here defined as simply respect for diversity: 'We wanted to provide a space for a creative encounter of different languages and cultures founded on mutual respect' (Kleczewska quoted in KLECZEWSKA and CHOTKOWSKI 2019). Such a multicultural production is not completely novel in the Polish theatre, yet it is still recognised by critics and spectators alike as rather unusual and not very common. This results from the relative homogeneity of the Polish society in the perspective imposed upon the Poles by Communist authorities after World War II. ${ }^{9}$

Significantly, such a uniform view of the Polish society still persists more than 30 years after 1989, and it seems that Kleczewska's production addresses this issue in a most topical manner, provoking spectators to reflect upon multiculturalism and openness

7 See http://teatr-polski.pl/spektakle/hamlet-\%D0\%B3\%D0\%B0\%D0\%BC\%D0\%BB\%D0\%B5\%D1\%82/

8 See the Teatr Polski Internet website: http://teatr-polski.pl/spektakle/hamlet-\%d0\%b3\%d0\%b0\%d0\% bc\%d0\%bb\%d0\%b5\%d1\%82/.

9 Before 1939 Poland was a multi-ethnic and multicultural society, which did not mean that what today is known as multiculturalism was (officially) considered positive. Still, cultural multivalence was an undeniable fact recognised by all levels of the society. 
to the other. This is topical in that the non-Polish language which stands out in the production is Ukrainian (cf. the title, poster, and the description of the production on the website of Teatr Polski are bilingual, written in Polish and Ukrainian, apart from English). With so many Ukrainians migrating to Poland in recent years and Ukrainian becoming the second most often spoken language in the country, Kleczewska (and Maciej Nowak, an artistic director of Teatr Polski) have employed actors and actresses from Ukraine (altogether, four out of nineteen, with Lutskiy cast as Hamlet). Witold Mrozek also notes the sociological ramifications of the decision to cast Ukrainian actors: 'Perhaps the basic meaning of the Ukrainian-ness of this Hamlet lies not in the production itself, but the whole situation around it, in acknowledging that we are living in a more and more multicultural country, one where the Ukrainians are a visible group, our next-door neighbours' (MROZEK 2019). Consequently, the presence of Ukrainian actors can be treated as a gesture of respect towards the Ukrainian minority and an invitation to come and see the production. ${ }^{10}$ At the same time, however, by having the cast multinational and multilingual the production sent a signal that the nationality or ethnic origin of the performers must not be considered a significant factor. ${ }^{11}$

Critics were not entirely satisfied with the ways in which the production addresses multi-culturalism and transnationalism. For example, Dariusz Kosiński found 'the intercultural nature of the production [...] surprisingly stereotypical' (KOSIŃSKI 2019), while Mike Urbaniak remarked that: 'It is difficult to talk about an intercultural dialogue when people of colour and different ethnic background were cast by the director as supernumeraries, hanging around according to pretentious choreography by Kaya Kołodziejczyk' (URBANIAK 2019). Likewise, with reference to the actors and actress playing Fortinbras, Obarska (2019) observed that persons of colour are given an important, yet minor role, which the critic treats as a rather perfunctory comment on the need for ethnic variety and openness to immigrants; furthermore, Obarska has commented that such desultory casting choices may be considered unintentionally racist (OBARSKA 2019). Certainly, the ethnic variety could have been more pronounced in the production; the lead is given to white actors. Despite the fact that 'Fortinbras as a multicultural chorus accompanies Hamlet's characters and spectators throughout the production' (Kleczewska quoted in KLECZEWSKA and CHOTKOWSKI 2019), they (Fortinbras) remain on the margins, occupying the centre only at the end of the performance. At the same time, Fortinbras, the Other, can be seen to symbolise a new beginning (both in the play and production). ${ }^{12}$ The various incarnations of Fortinbras speak in different voices and perform in different bodies and different styles, albeit in a kind of unison,

10 This welcoming strategy worked, as I did hear Ukrainian audience members commenting on the performance during and after the show I attended in May 2019.

11 The point was raised in a letter of protest that the actors Purandare, Fall, and Mafa addressed to a Polish critic, Witold Mrozek, who in his review termed their Fortinbras 'savage' (MROZEK 2019); the performers made it clear that their nationality does not matter in the impersonation of a fictional character ('Aktorzy piszą do recenzenta' [Actors write to a reviewer], 2019).

12 As Henry Zbierski reminds us, roles such as Fortinbras are necessary in a Shakespearean tragedy as a dramatic factor which helps restore the upset order (ZBIERSKI 1988: 389). 
underscoring the necessity for diversity as well as its inevitability. It is important to remember that Fortinbras also provides a smooth transition to the beginning of the next performance: 'the entry of the Fortinbrases is accompanied by an Indian song of victory sung in Sanskrit, which resurrects the characters as the story begins anew' (Chotkowski quoted in KLECZEWSKA and CHOTKOWSKI 2019). As Alona Szostak characterises the effect: 'We call it a loop [two performances in a row]. It is like a wheel which keeps on turning. Or a machine, Hamletmachine' (Szostak quoted in BEZDUSZNA 2019). Consequently, Fortinbras functions as a new beginning in more than one dimension.

As Wanda Świątkowska (2019) notes in her study of Polish post-war productions of Hamlet, Fortinbras is a character particularly important in the Polish theatrical culture after 1945, one which functions as a litmus test reflecting the political situation in the country. Swiątkowska discusses not only theatrical adaptations of this figure (both in Shakespeare's Hamlet and Stanisław Grochowiak's play Król IV) but also poetic incarnations (poems by Zbigniew Herbert and Witold Wirpsza) as well as cinematic representations (in Hamleś, a student film by Jerzy Skolimowski). The scholar highlights the significance of the character in Polish culture in general (ŚWIĄTKOWSKA 2019: 141-195). In other words, Fortinbras has been seen as figuring Poland itself. Consequently, Kleczewska's multicultural and multilingual Fortinbras(es) adds to the long list of how Poland has been represented on Polish stages, e.g., in 1945, 1989, and 2019, respectively as a liberator, a dictator, or a child (ŚWIĄTKOWSKA 2019: 141-195). Kleczewska's multivocal Fortinbras emphasises the significance of cultural and ethnic variety, redefines Polish-ness and attempts to radically redraw the map of the 'Polish' theatre in particular and culture in general. It is not that the Other needs to be integrated in the society since the Other becomes the foundation of the society.

It is noteworthy that Fortinbras represents not only ethnic, but also gender variety. The woman as the Other is yet another crucial issue in the production. Alona Szostak's Gertrude and Teresa Kwiatkowska's Ophelia are examples of how women are still objectified in the contemporary world, as clichéd as this may sound. Tomasz Domagała describes Gertrude in the production as a

[w]oman/object, deceived by her brother-in-law and used by him only as a means to rise to power and who drowns her sorrows and humiliation in alcohol. In the Mousetrap scene she plays the spoilt star in order to quickly open up her aching, suffering heart to her son. Szostak's performance of this emotional rollercoaster is superb. (DOMAGAŁA 2019)

Perhaps one more scene provides the key to the understanding of the tragedy of Gertrude in the play and the production. Kleczewska has Claudius dictate to Gertrude the letter to the English king ordering him to kill the note's deliverer. She types it on a computer, at first completely unaware of what it will contain and gradually becoming more and more terrified as she finds out what fate Claudius has in store for Hamlet, her son. She wants to stop, but the King makes her type the entire letter until she is utterly humiliated and devastated. 
As Gertrude is presented as helpless, disgraced, and objectified in the production, so is Ophelia, whose voice and body belong to a mature actress (Kwiatkowska is over 60). The scene of her madness is as intensely moving and, indeed, as shocking as the scene of the Queen's typing the letter to the English monarch. Ophelia wears a white wedding dress with the red (and girlishly kitschy) inscription: 'I love you' on its front. She runs through the crowd of spectators, accosting some of them. Ophelia here is not a young girl, yet she has been duped by the promises of love from a younger, handsome lover. Deceived again, now for the last time, as her next step will be suicide. Critics appreciated Kleczewska's decision to cast Ophelia in such a surprising way. Stanisław Godlewski observes that 'Teresa Kwiatkowska's Ophelia is completely devoid of childishness, which the role can lead to. Kwiatkowska creates an image of a woman who out of her own will rejects dignity and whose madness results from profound solitude and the awareness of a wasted chance' (GODLEWSKI 2019). Chotkowski, in turn, emphasises the 'Otherness' of woman, especially elderly woman, thus doubly stigmatised and further marginalised: 'Women of a certain age are denied the right to love and desire, for which - like Ophelia - they often pay a huge price' (GODLEWSKI 2019).

There is one more category of the Other that Kleczewska introduces, again spectacularly, in the production. Just as Ophelia runs counter to the present-day cult of the young and beautiful, Horatio here is the opposite of handsome and fit. Confined to a wheelchair, with a heavily twisted body and speech disfunction (he needs to use a computer programme to be understood), he resembles the late Stephen Hawking. He forces the spectator to make an effort not only to watch him but to approach him, as the audience may be considering whether or not the actor playing this role is disabled. Sikorski's performance is so convincing that many spectators left the production in the belief that Kleczewska cast a person who was genuinely confined to a wheelchair and suffers from paraplegia and a speech impediment. In this way, the creative choices made reflect the issue of another Other in the modern world and how Others are still marginalised, if only due to architectural barriers. On the other hand, with an obvious similarity to Hawking in mind, Kleczewska calls Horatio 'the mastermind of Elsinore' through which the voice of the ghost can be heard, as the Ghost's lines are delivered by Horatio (KLECZEWSKA and CHOTKOWSKI 2019). Horatio thus becomes more instrumental in triggering events than in the original play; despite his disability he is nonetheless granted greater agency.

\section{Conclusion}

Maja Kleczewska's Hamlet/Гамлет is certainly a memorable production which significantly contributes to the discussion about the role of theatre, spectating, immigrants in contemporary Polish society thirty years after the rise of the Iron Curtain. Kleczewska asks questions about our openness to the Other in multiple forms, especially perhaps people of different national/ethnic backgrounds. The production makes us aware of the fact that such questions still need to be addressed and examined, and our attention 
needs to be drawn towards them. Kleczewska's production is a loud voice in the uneasy discussion about the nature of modern society, and may prove to be socially and artistically relevant and influential.

\section{Bibliography}

ASHCROFT, Bill, Gareth GRIFFITH and Helen TIFFIN. 2007. Post-Colonial Studies. The Key Concepts. 2nd edition. London and New York: Routledge, 2007.

Aktorzy piszą do recenzenta [Actors Write to a Reviewer]. 2019. [accessed on 9.07.2019]. Available online at http://www.e-teatr.pl/pl/artykuly/276671.html.

BEZDUSZNA, Anastazja. 2019. Alona Szostak gra Szekspira. Nie dam ci umrzeć, Królowo [Alona Szostak Plays Shakespeare. I won't let you die, Queen]. Polska Gtos Wielkopolski 149 (09. 07. 2019). [accessed on 15.11.2019]. Available online at http://www.e-teatr.pl/pl/artykuly/277779. html.

BOCHNIARZ, Marek S. 2019. Ziemia im poddana [The Earth Subdued by Them]. kultura. poznan.pl (10. 06. 2019). [accessed on 2.11.2019]. Available online at_http://www.e-teatr.pl/pl/ artykuly/276474.html.

DOBROWOLSKI, Piotr. 2019. Symultana [Simultaneous Play]. Teatr 7-8 (31. 07. 2019). [accessed on 15.11.2019]. Available online at_http://www.e-teatr.pl/pl/artykuly/278441.html.

DOMAGAŁA, Tomasz. 2019. Myszy i ludzie - o Hamlecie Mai Kleczewskiej w Teatrze Polskim w Poznaniu [Of Mice and Men - on Maja Kleczewska's Hamlet in Teatr Polski in Poznań] (11. 06. 2019). [accessed on 20.11.2019]. Available online at http:/ / domagalasiekultury.pl/2019/06/11/ myszy-i-ludzie-o-hamlecie-w-rez-mai-kleczewskiej-w-teatrze-polskim-w-poznaniu/.

FANON, Frantz. 1963. The Wretched of the Earth. Transl. by Constance Farrington. New York: Grove Press, 1963.

GODLEWSKI, Stanisław. 2019. Elsynore w Starej Rzeźni [Elsinore in Stara Rzeźnia]. Gazeta Wyborcza Poznań online (10. 06. 2019). [accessed on 24.10.2019]. Available online at http:// www.e-teatr.pl/pl/artykuly/276472.html.

HAMLET/ГAMIET in Teatr Polski. 2020. [accessed on 26.09.2020]. Available online at http:// teatr-polski.pl/spektakle/hamlet-\%d0\%b3\%d0\%b0\%d0\%bc\%d0\%bb\%d0\%b5\%d1\%82/.

KOSIŃSKI, Dariusz. 2019. Mam do tej ziemi prawo [I Have Some Rights in This Kingdom]. Tygodnik Powszechny 26 (6. 07. 2019). [accessed on 24.11.2019]. Available online at http://www.eteatr.pl/pl/artykuly/277650.html.

KOWALCZE-PAWLIK, Anna. 2019. Echa festiwalu: słuchanie w teatrze, słuchanie teatru [Echoes of the Festival: Listening in Theatre, Listening to Theatre]. In Jacek Fabiszak, Marta Gibińska and Jan Grzanka (eds.). Reminiscencje festiwalowe. 23 Festiwal Szekspirowski. Gdańsk: Polskie Towarzystwo Szekspirowskie, 2019: 93-126.

KOWALCZE-PAWLIK, Anna. 2020. Personal email correspondence with the author (25. 05. 2020).

KYZIOŁ, Aneta. 2019. Stara Rzeźnia Polska [Stara Rzeźnia Poland]. Polityka 25 (18. 06. 2019. [accessed on 25.11.2019]. Available online at http://www.e-teatr.pl/pl/artykuly/276890.html. 
KLECZEWSKA, Maja and Łukasz CHOTKOWSKI. 2019. Kłamstwo staje się prawdą w Elsynorze [The Lie Becomes the Truth in Elsinore]. Interview by Zuzanna Liszewska. Przekrój online (23. 08. 2019). [accessed on 28.10.2019]. Available online at_http://www.e-teatr.pl/pl/artykuly/278970.html.

MROZEK, Witold. 2019. Ukraiński Hamlet w rzeźni o końcu Europy [Ukrainian Hamlet in an Abattoir at the End of Europe]. Gazeta Wyborcza online (10. 06. 2019). [accessed on 20.11.2019]. Available online at http://www.e-teatr.pl/pl/artykuly/276472.html.

OBARSKA, Marcelina. 2019. Hamlet jest akcją [Hamlet is Action]. culture.pl (21. 06. 2019). [accessed on 20.11.2019]. Available online at http://www.e-teatr.pl/pl/artykuly/276976.html.

PIKLI, Natália. 2020. Personal email correspondence with the author, (31. 05. 2020).

SPIVAK, Gayatri Chakravorty. 1985. The Rani of Sirmur: An Essay in Reading the Archives. History and Theory 24 (October 1985): 3: 247-272.

ŚWIĄTKOWSKA, Wanda. 2019. Hamlet.pl Myślenie Hamletem w powojennej kulturze polskiej [Hamlet.pl Thinking Hamlet in the Polish Post-war Culture]. Kraków: Wydawnictwo Uniwersytetu Jagiellońskiego, 2019

URBANIAK, Mike. 2019. Hamlet w rzeźni [Hamlet in an Abattoir]. vogue.pl (17. 06. 2019). [accessed on 13.11.2019]. Available online at http://www.e-teatr.pl/pl/artykuly/276847.html.

WITTCHEN-BAREŁKOWSKA, Agata. 2019. Słowa nie mają już nic do powiedzenia [Words Have Nothing to Say Yet]. kulturaupodstaw.pl (27. 06. 2019). [accessed on 24.10.2019]. Available online at http://www.e-teatr.pl/pl/artykuly/277258.html.

WOŁOSZ-SOSNOWSKA, Anna. 2020. Hamlet Mai Kleczewskiej jako zwierciadło współczesnej Polski i Poznania [Maja Kleczewska's Hamlet as a Reflection of Contemporary Poland and Poznań]. 'Szekspir w czasie teraźniejszym (złożonym)' Conference. Polish Shakespeare Society. 23 April 2020, Gdańsk.

ZBIERSKI, Henryk. 1988. William Shakespeare. Warszawa: Wiedza Powszechna, 1988. 


\section{dr hab. Jacek Fabiszak, prof. UAM}

Department of Studies in Culture, Faculty of English, Adam Mickiewicz University, Collegium Heliodori

ul. Grunwaldzka 6, 60-780 Poznań, Poland

fabiszak@amu.edu.pl

ORCID: https://orcid.org/0000-0003-3369-091X

Jacek Fabiszak teaches cultural history, theory, theatre history and Shakespeare at the Faculty of English, Adam Mickiewicz University, Poznań, Poland. His research interests include English Renaissance theatre and drama and their stage, televisual and filmic transpositions. He has published and presented papers at conferences on Shakespeare's plays, with one of his major publications in this area the study Polish Televised Shakespeares (2005). He also applies linguistic and sociological tools in the analysis of drama, which has resulted in the publication of Shakespeare's Drama of Social Roles (2001), a book that attempts to interpret Shakespeare's last plays in light of the theory of social roles and speech act theory. He has co-authored Szekspir. Leksykon [Shakespeare. A Lexicon, 2003], co-edited Czytanie Szekspira [Reading Shakespeare], and written on Christopher Marlowe, both on play texts (focusing on imagery) and screen versions (especially Edward II). He is the head of the Department of Studies in Culture at the Faculty of English, Adam Mickiewicz University in Poznań. 